\title{
PENGARUH MODEL PEMBELAJARAN PICTURE AND PICTURE TERHADAP KEMAMPUAN MENULIS KARANGAN DESKRIPSI SISWA KELAS VII SMP NURUL AZMAN GUNUNG PUTRI BOGOR
}

\author{
Ryan Hidayat \\ Dosen Program Studi Arsitektur Universitas Indraprasta PGRI \\ ryansastra3@gmail.com
}

\begin{abstract}
Abstrak
Tujuan untuk mengetahui ada tidaknya pengaruh model pembelajaran picture and picture terhadap kemampuan mengarang deskripsi siswa kelas VII SMP Nurul Azman. Metode yang digunakan dalam penelitian ini adalah metode eksperimen. Sampel yang diambil menggunakan teknik purposive sample sehingga dapat sampel siswa kelas VII SMP Nurul Azman Gunung Putri, Bogor, sebanyak 30 anak sebagai kelas eksperimen. Data dalam penelitian ini yaitu eksperimen kemampuan menulis karangan deskripsi siswa. Teknik analisis data yang digunakan untuk menguji hipotesis adalah dengan menggunakan uji-t, pada taraf signifikansi $\alpha=0,05$. Hasil penelitian diperoleh $t_{\text {hitung }}>t_{\text {tabel }}(3,756>2,040)$ artinya $H 1$ diterima. Dengan demikian kesimpulan yang diperoleh adalah terdapat pengaruh yang signifikan model pembelajaran picture and picture terhadap kemampuan menulis karangan deskripsi siswa kelas VII.
\end{abstract}

Kata kunci : Model Pembelajaran Picture and Picture, Kemampuan Menulis Karangan Deskripsi

\begin{abstract}
The purpose of know the whereabouts of the influence of learning model picture and picture of the ability of concocted description of student vii junior high school Nurul Azman. Methods used in this research in the experimental methods. Samples to be taken using a technique purposive sample so that it can be sample vii junior high school students Nurul Azman Gunung Putri, Bogor, as many as 30 kids as a class experiment. Data in research is experiment since writing a wreath of a description of students. Technique analysis the data used to test hypotheses is by using uji-t, the first significance $\alpha=0,05$. The results of the study obtained $t_{\text {hitung }}>t_{\text {tabel }}(3,756>2,040)$ means $H 1$ accepted. Thus a conclusion that obtained was significant is the learning model picture and picture of the ability of writing a wreath of a description of students VII.
\end{abstract}

Keywords : Learning Model Picture and picture, Ability of Writing a Wreath

\section{PENDAHULUAN}

Salah satu masalah yang dihadapi dunia pendidikan adalah masalah lemahnya proses pembelajaran. Dalam proses pembelajaran, anak kurang didorong untuk mengembangkan kemampuan berpikir. Proses pembelajaran di dalam kelas diarahkan kepada kemampuan anak untuk menghafal informasi, otak anak dipaksa untuk mengingat dan menimbun berbagai informasi tanpa dituntut untuk memahami informasi yang diingatnya itu untuk menghubungkannya dengan kehidupan sehari-hari. Akibatnya, ketika anak didik lulus dari sekolah, mereka pintar secara teoritis, tetapi mereka miskin aplikasi.

Dalam kurikulum tingkat satuan pendidikan Sekolah Menengah Pertama (SMP) dalam mata pelajaran bahasa Indonesia, di antaranya mencakup aspek 
keterampilan berbicara, menyimak, membaca, dan menulis. Keempat keterampilan aspek tersebut sangat penting, penulis mengambil dari keempat aspek di atas adalah aspek menulis. Seorang siswa SMP terutama siswa kelas tujuh diharapkan sudah mampu dalam mengembangkan aspek keterampilan menulis. Terutama dalam hal menulis beberapa kalimat menjadi sebuah paragraf yang memiliki makna.

Menulis pada hakikatnya merupakan keterampilan dasar yang harus dimiliki oleh siswa. Pada setiap pembelajaran bahasa Indonesia khususnya keterampilan ini sangat dibutuhkan. Menulis tidak hanya untuk mengekspresikan imajinasi ke dalam bahasa tulis, namun sebagai upaya mengembangkan kreativitas siswa dalam menulis. Salah satu yang sering ada dalam kegiatan beajar mengajar di sekolah menengah pertama adalah menulis karangan deskripsi. Siswa diharapkan dapat menulis karangan deskripsi dengan baik. Namun, pada kenyataan yang terjadi di lapangan, siswa seringkali mengalami kesulitan menulis karangan deskripsi. Siswa berkeluh bahwa sangat sulit menguraikan ide-ide yang ada di pikiran untuk dituangkan dalam tulisan. Siswa sulit mendapatkan stimulus berupa media untuk merangsang pikirannya dalam menulis.

Dalam mengembangkan aspek kemampuan menulis dalam hal ini menulis karangan deskripsi dapat dilakukan dengan model pembelajaran picture and picture. Dilihat dari picture and picture berarti ini mengenai sebuah gambar. Menurut Daryanto (Daryanto, 2010:107) gambar merupakan "media intruksional yang harus dipilih dan dipergunakan sesuai dengan tujuan khusus mata pelajaran". Anak dapat mengaitkan pengalaman sehari-harinya dengan gambar yang sudah disediakan oleh guru dan ia akan dapat berimajinasi dengan gambar tersebut. Berawal dari imajinasinya tersebut anak dapat menuangkannya dalam bentuk tulisan yang akan menjadi sebuah karangan deskripsi.

Melalui model pembelajaran picture and picture, diharapkan anak dapat mengembangkan kemampuan menulisnya, terutama dalam menulis karangan deskripsi, karena dalam sebuah gambar terdapat berbagai hal yang dapat membuat anak berimajinasi dalam pikirannya.

\section{TINJAUAN PUSTAKA \\ Model Pembelajaran Picture and Picture}

Model pembelajaran adalah bentuk pembelajaran yang tergambar dari awal sampai akhir yang disajikan secara khas oleh guru di kelas. Dalam model pembelajaran terdapat strategi pencapaian kompetensi peserta didik dengan pendekatan, metode, dan teknik pembelajaran. Dalam buku Trianto, Arends mengemukakan bahwa "setiap model mengarahkan kita dalam merancang pembelajaran untuk membantu peserta didik mencapai tujuan pembelajaran". (Trianto, 2007:1) Namun, tidak ada model pembelajaran yang paling efektif untuk semua mata pelajaran atau untuk semua materi.

Pemilihan model pembelajaran untuk diterapkan guru di dalam kelas mempertimbangkan beberapa hal: 1) tujuan pembelajaran, 2) sifat materi pelajaran, 3) ketersediaan fasilitas, 4) kondisi peserta didik, 5) alokasi waktu yang tersedia.Dalam buku Trianto, Nur menyatakan, "Model pembelajaran mengacu pada pendekatan pembelajaran yang akan digunakan, termasuk di dalamnya tujuan-tujuan pengajaran, tahap-tahap kegiatan pembelajaran, lingkungan pembelajaran, dan pengelolaan kelas". (Trianto, 2007:1) 
Langkah-langkah model pembelajaran picture and picture. (Departemen Pendidikan Nasional)

1. Guru menyampaikan kompetensi yang ingin dicapai.

2. Menyajikan materi sebagai pengantar.

3. Guru menunjukkan/memperlihatkan gambar-gambar kegiatan berkaitan dengan materi.

4. Guru menunjuk/memanggil siswa untuk mengurutkan gambar-gambar menjadi urutan yang logis.

5. Guru menanyakan alasan/dasar pemikiran urutan gambar tersebut.

6. Dari alasan/urutan gambar tersebut guru memulai menanamkan konsep / materi sesuai dengan kompetensi yang ingin dicapai.

7. Kesimpulan/rangkuman.

Model pembelajaran picture and picture adalah model pembelajaran yang menggunakan media gambar. Model ini baik untuk mengembangkan kemampuan imajinasi anak, dari imajinasi dituangkan ke dalam tulian. Dari media gambar siswa lebih cepat paham, karena terdapat beberapa proses dari melihat, pada saat melihat siswa berpikir. Hal ini menunjukan bahwa media gambar sangat berguna untuk proses pembelajaran.

\section{Karangan Deskripsi}

Fungsi bahasa sangat penting dalam dunia mengarang. Bahasa adalah penemuan manusia, yang paling unggul dan menjadi alat yang amat penting untuk membangun kebudayaan manusiawi. Manfaat terbesar dari bahasa adalah bahwa dapat dipergunakan untuk mengutarakan gagasan, perasaan serta maksud kita. Bahasa yang dituangkan dalam suatu tulisan dapat menyampaikan gagasan kepada orang yang jauh dari penulis baik menurut ruang dan waktu.
Karangan merupakan karya tulis hasil dari kegiatan seseorang untuk mengungkapkan gagasan dan menyampaikannya melalui bahasa tulis kepada pembaca untuk dipahami. Nurudin mengemukakan bahwa "menulis yang baik adalah menulis yang bisa dipahami oleh orang lain".(Nurudin, 2010:4)

Penulisan karangan deskripsi tak ubahnya seorang pelukis. Hal yang membedakan keduanya adalah media yang digunakan, yaitu pena dan kanvas. Finoza berpendapat bahwa (Finoza, 2009:198) "karangan deskripsi merupakan karangan yang lebih menonjolkan aspek pelukisan sebuah benda sebagaimana adanya". Gie mengungkapkan Deskripsi berasal dari bahasa description yang berarti "bentuk pengungkapan yang menggambarkan berbagai serapan pengarang dengan segenap indranya yang bermaksud menimbulkan citra yang sama dalam diri pembaca". (Gie, 1992:18)

Karangan merupakan hasil gagasan seseorang dari daya ingat melalui pengalaman yang dialami. Sebenarnya mengarang tidak harus tertulis. Seperti halnya berkomunikasi, kegiatan mengarang juga menggunakan bahasa sebagai mediumnya dapat berlangsung secara lisan. Bertalian uraian di atas mengarang juga merupakan pekerjaan merangkai kata, kalimat, untuk menjabarkan topik.

\section{METODE PENELITIAN}

Metode yang digunakan dalam penelitian ini adalah metode eksperimen. Arikunto mengemukakan (Arikunto, 2004:207) "Penelitian eksperimen adalah penelitian yang dimaksudkan untuk mengetahui ada tidaknya akibat dari "sesuatu" yang dikenakan pada subjek selidik". Penelitian ini menggunakan metode eksperimen 
dengan model one group pretest posttest design yaitu eksperimen yang dilaksanakan pada satu kelompok saja tanpa kelompok pembanding (Arikunto, 2004:212). Kelompok yang digunakan hanya melibatkan satu kelompok. Satu kelompok tersebut merupakan kelompok eksperimen yang mendapatkan perlakuan.

Kelompok eksperimen ini diberikan pretest. Hal ini dilakukan untuk mengetahui seberapa besar kemampuan menulis sebelum diberi perlakuan. Setelah diberikan perlakuan berupa penggunaan model pembelajaran picture and picture, kelompok ini diberikan posttest. Hasil dari pretest dan posttest tersebut kedua datanya akan dijadikan bahan untuk pengujian hipotesis.

\section{HASIL DAN PEMBAHASAN}

Penelitian ini mengenai pengaruh model pembelajaran picture and picture terhadap kemampuan menulis karangan deskripsi siswa kelas VII SMP Nurul Azman. Untuk mengetahui data kemampuan menulis karangan, siswa diberikan tes mengarang deskripsi yang dilakukan pada pretest dan post test, kemudian data tersebut dianalisis. Hasil pretest dan posttest dibandingkan untuk melihat perubahan atau peningkatan skor sebelum diberikan perlakuan dan setelah diberikan perlakuan. Deskripsi data terdiri dari penyajian skor hasil pretest dan posttest, nilai rata-rata pretest posttest, nilai terendah pretest posttest, dan nilai tertinggi pretest posttest. (perhitungan uji-t lihat lampiran).

Tabel 1

Data Hasil Pretest-Post test Kemampuan Menulis Karangan

\begin{tabular}{|l|l|c|c|}
\hline No & \multicolumn{1}{|c|}{$\begin{array}{c}\text { Deskripsi } \\
\text { Data }\end{array}$} & Pretest & $\begin{array}{c}\text { Post } \\
\text { test }\end{array}$ \\
\hline 1 & $\begin{array}{l}\text { Nilai } \\
\text { tertinggi }\end{array}$ & 85 & 90 \\
\hline 2 & $\begin{array}{l}\text { Nilai } \\
\text { terendah }\end{array}$ & 55 & 60 \\
\hline 3 & $\begin{array}{l}\text { Rata-rata } \\
\text { (Mean) }\end{array}$ & 71,9 & 74,2 \\
\hline 8 & $\begin{array}{l}\text { Jumlah Skor } \\
\text { Data }\end{array}$ & 2157 & 2226 \\
\hline
\end{tabular}

Tabel 2

Data Hasil Perhitungan Pretest dan Post test

\begin{tabular}{|c|l|c|c|c|c|c|}
\hline No & \multicolumn{1}{|c|}{ Nama } & Pretest & Post test & $\mathrm{d}$ & $\mathrm{xd}$ & $x^{2} d$ \\
\hline 1 & AH & 55 & 60 & 5,000 & 2,700 & 7,290 \\
\hline 2 & AM & 85 & 83 & $-2,000$ & $-4,300$ & 18,490 \\
\hline 3 & AS & 65 & 70 & 5,000 & 2,700 & 7,290 \\
\hline 4 & AJ & 65 & 70 & 5,000 & 2,700 & 7,290 \\
\hline 5 & AN & 67 & 60 & $-7,000$ & $-9,300$ & 86,490 \\
\hline 6 & AR & 80 & 77 & $-3,000$ & $-5,300$ & 28,090 \\
\hline 7 & BT & 85 & 90 & 5,000 & 2,700 & 7,290 \\
\hline 8 & DR & 73 & 77 & 4,000 & 1,700 & 2,890 \\
\hline 9 & DN & 70 & 75 & 5,000 & 2,700 & 7,290 \\
\hline 10 & DS & 67 & 70 & 3,000 & 0,700 & 0,490 \\
\hline 11 & DF & 85 & 85 & 0,000 & $-2,300$ & 5,290 \\
\hline 12 & HM & 84 & 88 & 4,000 & 1,700 & 2,890 \\
\hline 13 & IH & 70 & 70 & 0,000 & $-2,300$ & 5,290 \\
\hline 14 & JL & 65 & 65 & 0,000 & $-2,300$ & 5,290 \\
\hline 15 & MA & 60 & 65 & 5,000 & 2,700 & 7,290 \\
\hline 16 & MH & 65 & 67 & 2,000 & $-0,300$ & 0,090 \\
\hline
\end{tabular}




\begin{tabular}{|c|c|c|c|c|c|c|}
\hline 17 & PP & 70 & 70 & 0,000 & $-2,300$ & 5,290 \\
\hline 18 & $\mathrm{RP}$ & 85 & 89 & 4,000 & 1,700 & 2,890 \\
\hline 19 & $\mathrm{RD}$ & 76 & 81 & 5,000 & 2,700 & 7,290 \\
\hline 20 & SS & 75 & 80 & 5,000 & 2,700 & 7,290 \\
\hline 21 & SA & 70 & 73 & 3,000 & 0,700 & 0,490 \\
\hline 22 & SR & 85 & 89 & 4,000 & 1,700 & 2,890 \\
\hline 23 & ST & 75 & 70 & $-5,000$ & $-7,300$ & 53,290 \\
\hline 24 & SA & 70 & 70 & 0,000 & $-2,300$ & 5,290 \\
\hline 25 & SN & 70 & 70 & 0,000 & $-2,300$ & 5,290 \\
\hline 26 & SM & 65 & 68 & 3,000 & 0,700 & 0,490 \\
\hline 27 & SY & 70 & 77 & 7,000 & 4,700 & 22,090 \\
\hline 28 & TR & 65 & 67 & 2,000 & $-0,300$ & 0,090 \\
\hline 29 & YL & 75 & 80 & 5,000 & 2,700 & 7,290 \\
\hline 30 & YS & 65 & 70 & 5,000 & 2,700 & 7,290 \\
\hline & Jumlah ( $\sum$ ) & 2157,000 & 2226,000 & 69,000 & & 326,300 \\
\hline & $\mathrm{Md}$ & & & 2,300 & & \\
\hline & $t_{\text {hitung }}=$ & \multicolumn{5}{|c|}{3,756} \\
\hline & $\mathrm{t}_{\text {tabel }}=$ & \multicolumn{5}{|c|}{2,040} \\
\hline
\end{tabular}

Uji-t menggunakan dua sampel (pretest dan post test) dengan uji dua sisi (two tailed test). Dari tabel tersebut diketahui dengan menggunakan rumus :

$$
\begin{aligned}
& M d=\frac{\sum d}{n}=\frac{69000}{30}=2,300 \\
& \sum x^{2} d=326,300
\end{aligned}
$$

Kemudian hasil tersebut dimasukkan dalam perhitungan Uji-t dengan menggunakan rumus :

$$
\begin{aligned}
t & =\frac{M d}{\sqrt{\frac{\sum x^{2} d}{n(n-1)}}} \\
& =\frac{2,300}{\sqrt{\frac{326,300}{30(29)}}} \\
& =\frac{2,300}{0,612} \\
& =3,756
\end{aligned}
$$

Kriteria pengujian :

Hipotesis alternatif $\left(\mathrm{H}_{1}\right)$ ditolak jika $t_{\text {hitung }}<t_{\text {tabel. }}$ Hipotesis alternatif $\left(\mathrm{H}_{1}\right)$ diterima jika $t_{\text {hitung }}>\mathrm{t}_{\text {tabel}}$.
Diketahui :

Harga ttabel dengan $\mathrm{dk}=29(\alpha=0,05)$, dari daftar distribusi adalah 2,040

Pengajuan hipotesis ini dengan menggunakan Uji-t yaitu uji perbedaan dua rata-rata. Uji-t dengan satu kelompok pretest dan posttest menggunakan uji dua sisi (two tailed test) dengan kriteria apabila $t_{\text {hitung }}>t_{\text {tabel }}$ maka $\mathrm{H}_{1}$ diterima dan jika $\mathrm{t}_{\text {hitung }}<\mathrm{t}_{\text {tabel }}$ maka $\mathrm{H}_{1}$ ditolak.

Berdasarkan hasil pengujian hipotesis menggunakan Uji-t maka diperoleh harga $t_{\text {hitung }}=3,756$ dan harga $\mathrm{t}_{\text {tabel }}=2,040$ dengan taraf signifikansi $\alpha=$ 0,05 . Dari hasil tersebut diketahui bahwa $t_{\text {hitung }}>t_{\text {tabel }}$ sehingga dapat disimpulkan bahwa kemampuan menulis karangan anak menjadi lebih baik setelah diberikan perlakuan penerapan model pembelajaran picture and picture atau dengan kata lain terdapat pengaruh yang signifikan dari penerapan model pembelajaran picture and picture terhadap kemampuan menulis karangan deskripsi siswa kelas VII SMP Nurul Azman. Berikut ini adalah tabel dari rangkuman Uji-t. 
Tabel 3

Hasil Uji-t Pretest-Posttest Satu Kelompok

\begin{tabular}{|c|c|c|c|c|}
\hline Keterangan & $\mathrm{db}$ & $\mathrm{t}_{\text {hitung }}$ & $\mathrm{t}_{\text {tabel }}$ & Signifikan $\alpha=0,05$ \\
\hline Perhitungan hasil uji-t & 29 & 3,756 & 2,040 & Signifikan \\
\hline
\end{tabular}

\section{SIMPULAN}

Penelitian ini mengkaji pengaruh model pembelajaran picture and picture terhadap kemampuan menulis karangan deskripsi siswa kelas VII. Penelitian ini hanya melibatkan satu kelas yaitu sebagai kelas eksperimen tanpa adanya kelas control. Kelompok eksperimen ini merupakan responden dari siswa kelas VII SMP dan mendapatkan perlakuan berupa penerapan model pembelajaran picture and picture.

Berdasarkan hasil perhitungan Pada tingkat signifikasi 0,05 terlihat bahwa $t_{\text {hitung }}=3,756$ dan $t_{\text {tabel }}=2,040$ sehingga $t_{\text {hitung }}>t_{\text {tabel, }}(3,756>2,040)$ berarti terdapat pengaruh model pembelajaran picture and picture terhadap kemampuan menulis karangan deskripsi siswa kelas VII, dengan demikian $\mathrm{H}_{1}$ diterima. Dengan demikian, dapat disimpulkan bahwa terdapat pengaruh yang signifikan dari penerapan model pembelajaran picture and picture terhadap kemampuan menulis karangan deskripsi siswa kelas VII. Dengan demikian semakin sering anak diberi gambar untuk berimajinasi maka kemampuan menulis karangannya semakin tinggi.

Berdasarkan simpulan dan implikasi yang telah dikemukakan, penulis mengajukan saran-saran sebagai berikut :

1. Bagi Guru Siswa

Diharapkan bagi siswa untuk terus berlatih keterampilan menulis. Siswa tahu bagaimana cara menulis, tetapi pada kenyataannya siswa seringkali mengalami kesulitan menulis.
2. Bagi Guru Bahasa Indonesia

Disarankan untuk guru menerapkan model pembelajaran picture and picture dalam pembelajaran bahasa Indonesia. Terutama hal-hal yang berkaitan dengan kemampuan menulis karangan deskripsi.

3. Bagi Lembaga Pendidikan

Diharapkan kepala sekolah sebagai salah satu pihak penentu kebijakan sekolah untuk dapat mendukung upaya peningkatan kualitas kemampuan menulis karangan siswa, diantaranya dengan menyediakan berbagai pendukung model pembelajaran picture and picture seperti berbagai media atau buku-buku yang menarik dan sesuai dengan karakteristik siswa.

4. Bagi Peneliti Selanjutnya

Hendaknya dapat mengembangkan penelitian selanjutnya dengan memasukkan variabel lain yang belum dimasukan dalam penelitian ini, ataupun untuk jenjang yang berbeda.

\section{DAFTAR PUSTAKA}

Arikunto, S. (2004). Managemen Penelitian. Jakarta : Rineka Cipta.

Daryanto. (2010). Media Pembelajaran. Yogyakarta : Gava Media.

Departemen Pendidikan Nasional (2010). Model-model Pembelajaran yang Efektif.

Finoza, L. (2009). Komposisi Bahasa Indonesia. Jakarta : Diksi Insan Mulia. 
Liang G, T. (1992). Pengantar Dunia Karang Mengarang. Yogyakarta : Liberty.

Nurudin. (2010). Dasar - dasar Penulisan. Malang : UMM Press.
Trianto. (2007). Model Pembelajaran Terpadu. Jakarta : Prestasi Pustaka Publisher. 